\title{
Exploring the Value of the Capability Approach for Vocational Education and Training Evaluation: Reflections from South Africa
}

\author{
Lesley Powell and Simon McGrath
}

\begin{abstract}
In the late 1990s, South Africa faced the three-fold challenge of reforming the apartheid-divided institutional landscape of vocational education and training (VET) institutions; ensuring equitable access to skills; and reorienting its skills development system in line with the nation's reinsertion into the global economy. A wave of institutional reforms was enacted which was followed by a large programme of evaluative research. While this body of work was both valuable and necessary, it nonetheless had several limitations. As part of efforts to overcome these, the authors suggest an alternative evaluation method that draws on insights from the 'capability approach'. By putting the needs of people first — rather than the needs of the economy — the capability approach emphasises social justice, human rights and poverty alleviation in VET evaluation. This approach is more focused on the values and goals of individuals and institutions, while retaining the economic rationale as a key analytical tool and emphasising the continued importance of evaluation for the improvement of delivery and outcomes.
\end{abstract}

\section{Introduction}

How we evaluate vocational education and training (VET) and the corresponding information sets we use is of considerable importance, as VET has moved to the centre of political reform targeted at unemployment, poverty alleviation and economic growth (McGrath, 2012a). As a result, VET systems are under constant and persistent political pressure to transform, and to do so in such a way that expands participation and raises its parity of esteem (Nieuwenhuis and Shapiro, 2004).

Evaluation research is seen as central to advancing the transformation of these systems. It generates evidence regarding what does and does not work, maintains accountability and evaluates the effectiveness of interventions. A

(C) Graduate Institute of International and Development Studies, 2014 ～DOI 10.1163/9789004281158_008 This is an open access chapter distributed under the terms of the Creative Commons Attribution- 
range of questions can be raised about evaluation itself, including its effectiveness and efficiency. In this chapter, we will highlight two main issues regarding VET evaluation. First, we examine the 'information basis' of evaluative research undertaken on the sector and the assumptions that are made as to the role and purpose of the sector in selecting these, as opposed to other, information sets. Second, we consider the processes of inclusion and exclusion that take place during evaluation research that lead to both the privileging and silencing of certain voices.

The primary purpose of this chapter is to explore the potential of the capability approach for VET evaluation. We do so by situating our discussion in our experiences of carrying out more traditional evaluations in the context of the South African public Further Education and Training (FET) college sector. Between 1999 and 2002, Powell was research manager of the College Collaboration Fund (CCF), a business-funded project worth more than EUR 10 million aimed at supporting the Department of Education (DoE) in transforming the then-technical colleges into a FET college sector. Between 2002 and 2004, McGrath was a research director at the Human Sciences Research Council of South Africa, overseeing the research, monitoring and evaluation component of the Danish-funded Support to Education and Skills Development (SESD) Programme - the largest ever donor-funded project in the sector. While recognising the benefit of these programmes, however, we are both motivated to now move beyond the core assumptions that underpinned evaluation in these programmes. Broadly speaking, we seek to link to our wider attempts to develop alternate theoretical accounts regarding the purposes of VET and its role in development thinking (e.g. McGrath, 2012b; Powell, 2012). In so doing, we engage closely with the United Nations Educational, Scientific and Cultural Organization's (UNESCO) call for a transformative approach to vocational education and training and improved evaluation approaches to support them (UNESCO, 2014). The significance of this chapter lies in its attempt to point towards a new approach to the practice of evaluating VET research, informed by the latest theoretical and policy developments in the field.

The chapter is proceeds as follows. In the next section, we provide a brief history of research on the FET college sector in South Africa since 1994, before focusing specifically on the approach to evaluation that dominated in this era. We then turn to a discussion of the central concepts of the capability approach as they apply to both the challenge of evaluation generally and its potential contribution to VET evaluation more specifically. The subsequent section considers the operational implications of the capability approach. This is followed 
by a discussion of the potential challenges of such an approach. The chapter concludes with a summary of our main points.

\section{A Brief History of Research on South African FET Colleges ${ }^{1}$}

South Africa's public FET colleges are relatively new institutions that exist at the crossroads between school, higher education and the world of work (Fisher et al., 2004). This positioning results in multiple, overlapping remits, including the challenges associated with being a major source of intermediate skills and the mandate to help address mass youth unemployment and its highly racialised distribution.

The 50 new FET colleges were established between 1998 and 2002, largely by merging previously racially segregated-technical colleges. Although the primary drive was deracialisation, there was also a recognition that the previous institutions had serious issues of quality, relevance, staffing and leadership. These concerns spurred several studies on the FET colleges, undertaken between 1994 and 2004. Given a very weak existing research base, the major focus of these studies was on developing indicators and an information set upon which the size and shape of the sector could be built and against which the transformation of the sector could be measured (Powell and Hall, 2000, 2002 and 2004).

The period from 2004 to 2009 saw the consolidation of the sector: the FET Colleges Act was passed; college principals appointed; common management systems developed; college councils trained; a EUR c. 200 million Recapitalisation Fund implemented; and a new FET curriculum introduced. As many of the policy frameworks formulated and implementation began, research shifted to an increasingly critical engagement with the policies' coherence and initial outcomes (McGrath et al., 2004; Papier, 2006).

Much of the research undertaken between 1994 and 2009 was funded either by the government directly, or by donors and businesses working in partnership with government (Wedekind, 2009). With few exceptions, this research privileged quantitative methodologies, and when qualitative methods were used, these eschewed interpretivist approaches in favour of descriptive 'hard data' upon which policy could be built and revised (see Fisher et al. 2003). At the institutional level, research pragmatically adopted a new public

1 This section draws substantially from Powell's (2013) critical review of South African FET college literature. 
management view of the colleges, and focused on aspects of institutional development such as governance and management systems (Geel, 2005), marketing strategies (Akoojee and McGrath, 2008) and the quality of teaching staff (Jaff et al., 2004). In contrast, theoretical work was seen as being of little value (McGrath, 2008).

The 2009 election of President Zuma, at least rhetorically, saw a shift away from neoliberalism and towards a 'developmental state' with a strong emphasis on South Africa's poor and marginalised. South Africa's new economic policy is committed to creating decent work and promoting a more inclusive economy. As part of the significant changes to government structures, a new Department of Higher Education and Training (DHET) was established, bringing the responsibility for higher education, further education and work-based skills together, with the latter repositioned from the Department of Labour. The establishment of the DHET is intended to build a 'single, coherent, differentiated and highly articulated post-school education and training system' (DHET, 2011, 4), and reflects, in part, an apparent response to researcher critiques of the disarticulation of the previous system (e.g. McGrath et al., 2004; Kraak et al., 2006). The advent of DHET has prompted a renewed debate on South Africa's skills sector and the FET colleges, characterised by three areas of concern:

1. The size of youth unemployment. South Africa has imported the British concept of NEET (not in employment, education or training), which accounts for an estimated 42 per cent of youth aged 18-24, or nearly 3 million people (Cloete, 2009).

2. The pervasive and persistent patterns of inequality in race, gender and class, which are reflected in access to, and success in, education and training.

3. The continued disjuncture between education and training and the skill needs of the economy, illustrated by the failure of FET colleges to produce 'the productive citizens' hoped for in South Africa's 'skills revolution'.

In response to these concerns, the DHET has decided to expand access to education and training by increasing participation in FET colleges (and other proposed post-school institutions) to 4 million learners by 2030 (DHET, 2011, xi). The shift in policy discourse towards an integrated and expanded post-school system focusing on 'the needs of the poor' emphasises dimensions that were previously largely absent. By highlighting the role colleges are to play in poverty 
alleviation, the DHET seeks to shift the traditional discourse regarding colleges away from solely meeting the needs of industry to incorporate a focus on the needs of learners and communities. Equally, the conceptualisation of the colleges as part of an integrated and differentiated post-school system reflects an awareness of the need to create institutions with a sensitivity to very different contexts, rather than attempting to make 'one size fit all'.

This ambitious new vision provides a unique opportunity to step beyond the productivist accounts that have dominated VET policy and research internationally. ${ }^{2}$ It was not surprising, therefore, that Minister Nzimande was a keynote speaker at the Third International Congress on Technical and Vocational Education and Training in Shanghai (May 2012), where UNESCO launched its new vision for a transformative approach. Ambitious policy statements and new theoretical accounts, however, are only part of the answer. It is clear that evaluation research is positioned as pivotal to the next stage of FET college transformation, due to is perceived ability 'differentiate between stronger and weaker institutions in order to provide appropriate support and leadership to both' (DHET, 2011, 20) and mark progress in this new and expanded remit. For these efforts to succeed, however, there must be a new evaluation for the new transformation. Prior to explicating to our vision for a new evaluative approach, it is necessary to reflect in some detail upon the VET evaluation orthodoxy.

\section{Evaluative Research on South African FET Colleges}

Whilst there have been major innovations in evaluation methodology internationally (discussed below), VET evaluation in developing countries has been slow to progress. Four standard metrics form the standard information set of systemic and institutional VET evaluation internationally:

1. Measures of participation provided through Gross and Net Participation Rates, which aim to determine student enrolment patterns and are analysed by student, programme and institutional type.

2. Measures of institutional efficiency and effectiveness, determined through academic efficiency indicators such as pass and throughput

2 See McGrath (2012b) and McGrath and Lugg (2012) for further discussion of productivist accounts of VET and their implications for VET research. 
rates, and resource efficiency indicators such as unit learner costs and lecturer to student ratios.

3. Measures of graduate employment, determined through graduate destination studies, which aim to verify the employment destinations of graduates.

4. Measures of employer and student satisfaction, generally determined quantitatively through student and employer surveys.

The first two of these metrics have been applied to the South African FET college sector in some detail, but the third remains underdeveloped and the fourth almost entirely absent.

\subsection{Measures of Participation}

Policy ambitions to expand VET enrolments in South Africa and many other countries of the world have made measures of participation a high priority for governments. This data is, however, fraught with problems stemming from the multimodal and programmatic complexities of VET systems (McGrath and Lugg, 2012). In South Africa, initial transformation focused on changing the student and staff demographics in terms of race and gender, and transforming the racially-segregated institutional landscape through institutional mergers (Powell, 2013). By 2000, the most significant progress in the sector was the change in the racial and (to a lesser extent) gender composition of the student body, with black enrolment increasing from 32 per cent in 1990 to 75 per cent in 1998, and female students increasing from 38 to 41 per cent of total learners (Cosser et al., 2011). The early 2000s policy goal of achieving equity in racial participation has been largely achieved in the student and staff body, although some concerns regarding the racial composition of senior management staff remain. The participation of women females, however, continues to be skewed towards certain programme areas.

\subsection{Measures of Institutional Efficiency and Effectiveness}

The new skills development system created in the first post-apartheid decade outlined the key objectives of a transformed education and training, which, in turn, shaped the institutional objectives of the transformed landscape. In each of the two main intervention programmes (CCF and SESD), these objectives were translated into performance dimensions, with corresponding indicators, against which the efficiency and effectiveness of FET colleges were to be determined. Although the details of the CCF and SESD approaches differ, they are each characterised by five key performance dimensions, as summarised in Table 7.1. 
TABLE 7.1 Performance dimensions and related indicators

\begin{tabular}{|c|c|c|}
\hline Dimension & Goal & Indicators \\
\hline $\begin{array}{l}\text { Leadership and } \\
\text { management } \\
\text { effectiveness }\end{array}$ & $\begin{array}{l}\text { To manage and lead a } \\
\text { transformed FET college } \\
\text { in line with FET college } \\
\text { legislation, to ensure } \\
\text { the college meets the } \\
\text { standards of an } \\
\text { efficient, high-quality } \\
\text { education and training } \\
\text { institution that is } \\
\text { responsive to the needs } \\
\text { of the labour market }\end{array}$ & $\begin{array}{l}\text { - Existing vision and mission } \\
\text { the FET legislation } \\
\text { - Establishment of effective manage- } \\
\text { ment teams } \\
\text { - Functioning and updated informa- } \\
\text { tion systems } \\
\text { - Effective knowledge sharing and } \\
\text { communication within the } \\
\text { institution } \\
\text { - Practice of responsible and } \\
\text { sustainable financial management } \\
\text { Existence of adequate infrastruc- } \\
\text { ture for teaching and learning } \\
\text { Existence of adequate infrastruc- } \\
\text { ture for management } \\
\text { Effective human resource capacity } \\
\text { management }\end{array}$ \\
\hline $\begin{array}{l}\text { Marketing and } \\
\text { communication }\end{array}$ & $\begin{array}{l}\text { To effectively market } \\
\text { the college to employers } \\
\text { and prospective } \\
\text { students }\end{array}$ & $\begin{array}{l}\text { - Existence of a marketing strategy } \\
\text { Existence of a marketing office or } \\
\text { personnel dedicated to the task of } \\
\text { marketing }\end{array}$ \\
\hline Learner support & $\begin{array}{l}\text { To provide learners with } \\
\text { the support required to } \\
\text { learn effectively, make } \\
\text { career decisions and } \\
\text { manage personal crises } \\
\text { through student } \\
\text { counselling }\end{array}$ & $\begin{array}{l}\text { - Implementation of academic } \\
\text { support programmes } \\
\text { - Implementation of learner support } \\
\text { programmes }\end{array}$ \\
\hline
\end{tabular}


TABLE 7.1 (cont.)

\begin{tabular}{|c|c|c|}
\hline Dimension & Goal & Indicators \\
\hline Responsiveness & $\begin{array}{l}\text { To achieve the employ- } \\
\text { ability of learners }\end{array}$ & $\begin{array}{l}\text { - Existence of good partnerships with } \\
\text { - } \text { Eublic/private sector } \\
\text { with communities } \\
\text { - Existence of good relationships } \\
\text { with other state bodies } \\
\text { - Possession of institutional capacity } \\
\text { to exercise leadership and develop } \\
\text { - } \text { skills programmes } \\
\text { - Learner employment tracking exists } \\
\text { Learners are employable }\end{array}$ \\
\hline $\begin{array}{l}\text { Teaching and } \\
\text { learning }\end{array}$ & $\begin{array}{l}\text { To provide high quality } \\
\text { teaching and learning }\end{array}$ & $\begin{array}{l}\text { - Existence of a functioning curricu- } \\
\text { lum development process } \\
\text { - Lecturers are suitably qualified } \\
\text { - Well-functioning staff development } \\
\text { processes are in place } \\
\text { - Development of a quality assurance } \\
\text { system }\end{array}$ \\
\hline
\end{tabular}

SOURCE: AUTHORS.

In the context of contemporary policy plans to expand the FET colleges, measures of institutional effectiveness and efficiency have taken on additional importance, as DHET is aware of the 'danger that quality will be compromised' (DHET, 2011, 28) by the rapid growth.

Together, these studies painted a picture of a FET college sector beset with institutional problems, including the poor capacity of governing councils, college management and lecturing staff, and unacceptably low throughput and pass rates.

\subsection{Measures of Employability}

Following on from measures of efficiency and effectiveness, the third metric of conventional assessment, as mentioned above, is employability, a key element of current international policy discourses on post-school education. Typically, employability is captured through graduate destination studies, 
and tracer studies more specifically. Currently, very few institutions have reliable data in this area. The data that is available is often either out-dated or so limited it fails to capture information regarding the nature of the work, the extent to which work relates to the field of study, or the nature of the employment contract. As a result, only a limited number of employment tracer studies have been undertaken in South Africa, notably by Cosser et al. (2003) and Gewer (2009), who argue that a low percentage of graduates are successful in the labour market and even fewer in an area of work related to the programme they studied.

Employability is central to the move to expand participation. The hope is that expanding access to education and training will ensure that 'those entering the labour market are qualified and competent to take up the employment and income generating opportunities that exist and that will exist as the economy grows and changes in the future' (DHET, 2011, viii). The aim is that this will then 'contribute to fundamentally reducing unemployment and poverty' (DHET, 2011, viii). Within this context, the need and demand for employment tracking studies able to monitor (ideally, increased) employment is likely to grow.

\subsection{Measures of Employer and Student Satisfaction}

The fourth, and remaining, area of measurement relates to employer and student satisfaction. Employer and student satisfaction studies have not been a serious part of the evaluation research undertaken in South Africa. Select interviews were undertaken as components of larger projects, but these were small in scale and not systematic in nature. The employer satisfaction studies that were undertaken, however, indicate that employers find it difficult to determine their skill needs and are unsure about what the FET colleges can do to meet them (Mercorio and Powell, 1999). In many cases, unless a partnership existed between the employer and the college, employers were unsure as to what percentage of their employees were trained at an FET college.

\subsection{The Limitations of the Orthodox Approach to VET Evaluation in South Africa (and Beyond)}

As key actors in delivering this first wave of South African VET evaluation research, we still believe it made an important contribution to the establishment and reform of South Africa's FET colleges and that many of its ambitious should continue to inform future approaches. Upon reflection, however, we believe it was insufficient, in six regards, for what must be done in the next phase. First, it reflected a narrow VET understanding of evaluation that was poorly attuned to developments elsewhere in evaluation methodologies, a 
point we will return to below. Second, it drew on a new public management view of institutional development, which, though grounded in the wider assumptions of South African policy reform, provides an inadequate account of institutional change and quality, both generally and in the South African context. ${ }^{3}$ Third, it underplayed the wider economic and labour market contexts in which providers operate, focusing on the 'failings' of learners and colleges rather than those of employers or government. Fourth, it displayed a methodological deafness to the voices of learners, lecturers and communities, instead assuming that employability was the only goal of FET. Fifth, as the traditional approach is not designed to evaluate or address the new policy concerns with social justice or human development, it is not fit-for-purpose for the new phase of transformation being envisaged in South African FET policy. Sixth, it does not engage sufficiently with the emerging UNESCO account of VET and human development, which appears better attuned both to trends in development theory and South Africa's increasing official emphasis on human development. Taken together, these weaknesses have led us to envision an alternative way of thinking about VET evaluation, outlined below, which draws on the insights of the capability approach.

\section{The Capability Approach}

By emphasising the quality of life and well-being of individuals, the capability approach offers a normative framework in alternative to the output and efficiency measures usually applied to social evaluation. A central commitment of this approach, informed by the principles of social justice and, more recently, by what Sen (2009) has termed 'comparative justice', is to the dignity of each person. At its core, the capability approach is about providing individuals with the opportunities to live lives they value, enabling them to become agents in their own life (Deneulin and Shahani, 2009). By putting the needs of people first, rather than the needs of the economy, the capability approach brings social justice, human rights and poverty alleviation to the forefront of the VET and skills development discourse.

The concepts of capabilities, functionings and freedom are central to the capability approach and, according to Sen, provide the best metric for interpersonal evaluations. Capabilities comprise 'what a person is able to do or be' and represent both 'the opportunity to achieve valuable combinations of

3 See McGrath (2010) for an exploration of the use of new public management logic in the South African FET college sector. 
human functionings' (Sen, 2005, 153) and the freedom to choose among them. Freedom, in the capability approach, has not only instrumental importance in providing a greater range of alternatives, but, as 'acting freely' and 'being able to choose are [...] directly conducive to well-being' (Sen, 1992, 50), it is also intrinsically important to individual fulfilment. Functionings, on the other hand, represent what a person actually does and the life that a person actually lives, as well as person's state of well- (or ill-)being.

While it might appear that attempting to distinguish between 'capabilities' (opportunities) and 'functionings' (doings) is a matter of splitting hairs, the distinction is crucial for social justice and identifying inequality of opportunity-both of which are elided in conventional approaches to VET evaluation. In this regard, the distinction between capabilities and functionings offers three advantages to the evaluation of VET. First, the distinction highlights the importance of human freedom by differentiating between what people actually do (functionings) and what they can do (capabilities). This thus allows for the consideration of the possibility that individuals might achieve the same functioning (for example, an FET qualification) but have significantly different opportunities from which to select. This differs markedly from conventional resource input-output approaches to VET evaluation, which tend to focus purely on functionings. The distinction highlights the choices that an individual has regarding what to achieve in a particular area and the array of opportunities from which they are able to choose. The key difference lies between choosing to do and doing, i.e. between choosing to have a particular functioning (or achievement) and having a particular functioning (Sen, 1992).

Second, the distinction enables VET evaluations to identify differences in individual ability to convert the characteristics of an ability (such as commodities or skills) into functionings (such as employment). Interpersonal variations in this conversion ability could be due to either individual or social factors (Robeyns, 2000). Hence, limiting analysis to functionings (be they resources, qualifications or abilities)—as done by conventional VET evaluations-does not provide sufficient leverage on individual well-being.

Third, the distinction between capabilities and functionings is crucial is the approach's key conceptualisation of poverty as consisting of capability deprivation across multiple dimensions. In the context where large numbers of FET students come from what Gewer (2009) describes as 'poverty-stricken family environments' $(2009,145)$ and policymakers are committed to positioning an expanded FET college sector as a central instrument in poverty alleviation, the importance of the above conceptualisation of poverty for the evaluation of 
FET colleges becomes clear. In this context, measures of participation, while instrumental to monitoring increased individual access to education and training, apply what Qizilbash and Clark (2002) describe as a 'vague' definition of poverty that fails to adequately capture its multiple dimensions. As a result, these approaches also fail to consider both the critical threshold that must be surpassed in each of the multiple dimensions of poverty for an individual to move beyond poverty and the ways in which FET colleges can contribute to this achievement. The result is that measures of participation tell us little about the ways in which colleges contribute (and could potentially contribute more) to poverty alleviation.

Fourth, the capability approach allows differential risks and costs to individuals to be identified by VET evaluations. It also allows for the recognition of the potential contradictions in capabilities individuals may encounter. This is critical for ensuring policy success, as without an understanding of the potential costs or risks of attending VET institutions, policies for expanded participation face the risk of failure. For instance, consider the contrast between a student who risks his family's financial well-being by leaving employment to enrol for full-time study at a FET college and a student who attends college with no financial risk to his family at all. Both students are enrolled for study, but they experience very different stresses over the course of their programme. Such nuanced differentials, the recognition of which is crucial to the fulfilment of FET colleges' mandate to alleviate poverty, are discounted and rendered invisible by the conventional VET evaluations which dominate contemporary research on South African FET colleges.

The capability approach stresses the analytical distinction between means and ends. In essence, it argues that we should be clear when attributing value to something (or somebody) whether we value it (or s/he) for its own sake, or because it makes something else that we truly value possible. For the capability approach, the purpose (or 'ends') of interpersonal evaluation is the expansion of capabilities (opportunities), and the freedoms to elect from these capabilities. As such, institutions and structures-including VET institutions-should be evaluated in terms of the 'causal importance that they have for individuals' well-being' (Alkire, 2008, 33). In other words, 'it is people's capabilities that must guide the evaluation rather than how much money, educational resources, or qualifications they are able to command' (Walker and Unterhalter, 2010, 4). Correspondingly, the analytical focus rests on the capabilities that matter to individuals and the extent to which institutional and socio-economic arrangements expand or constrict individuals' capabilities, rather than on the institutional structures themselves. 
Through its focus on human well-being, the application of the capability approach to education and training in South Africa suggests a new set of questions for VET evaluation that asks, 'Do they [the social policies] really improve [people's] prospects in terms of capabilities?' (Bonvin and Farvaque, 2006, 3). Or, in the terms of the FET colleges specifically, do these institutions serve to expand or to constrict the capabilities, functionings and freedom of FET college students? South Africa's policy ambition is to create increased participation in an expanded FET college sector, but what valuable opportunities will these larger colleges offer, and how do we identify which opportunities matter to these students? This chapter argues that current approaches to evaluation, while useful for political and institutional accountability, are silent on these important matters. The capability approach, in contrast, raises a number of questions pertinent to the well-being of FET college students that differ to those considered by conventional approaches and that cannot easily be answered by the information sets generated by past VET evaluations. These questions include the following:

- Which dimensions of institutional functioning enable individuals to expand the capabilities they value and which serve to limit and constrict the expansion of capabilities and functionings?

- Which capabilities and functionings matter to students and to what extent are these being addressed by existing institutional arrangements, cultures and the pedagogic approach of VET?

- How does expanding the capabilities and functionings of an individual VET student contribute to the development of their families and communities?

- Given the existing institutional arrangements and pedagogic design of VET, do all students in the sector have the same opportunities to participate in and to succeed in VET?

The practical value of the capability approach is that it goes beyond providing an abstract, theoretical notion of social justice to provide a practical framework through which social justice can be enacted, monitored and evaluated through the lived lives of human beings (Walker, 2005). Reflecting on the contribution the capability approach makes to higher education, Walker notes that 'these are attractive ideas for higher education' but, she asks, 'how might they be applied for more practical evaluation purposes?' $(2008,477)$. The capability approach is similarly attractive, if not more so, for VET, than for higher education, as through its commitment to human well-being, it challenges the 
neoliberal underpinnings of VET policy that prioritise human resource development (McGrath, 2012b; Powell, 2012). The tricky question of how to operationalise the capability approach for practical purposes, however, remains. As Alkire writes: 'proof must be in the pudding' $(2008,1)$.

A first step in operationalising the capability approach is provided by Bonvin and Farvaque (2006), who argue that it affects evaluation on two levels: the substantial and the procedural. The substantial level involves the actual information sets upon which we base our evaluations, which are in turn driven by the kinds of questions asked above. The procedural level relates to the processes involved in deciding on the information sets and gathering the information required. With respect to the substantial level, Bonvin and Farvaque (2005) argue that the information upon which we base our evaluations 'is not neutral', as decisions are made during evaluations as to what to measure, which information sets are to applied to these measures and, conversely, what will not be measured and which information sets will not to be included. Core to the 'substantial level' of evaluation, as discussed above, is the importance of human flourishing, as conceptualised by the notions of 'capabilities', 'functionings' and 'freedom'. Tikly explains that 'from a human capabilities perspective', this suggests that 'evaluation of VET systems whilst important needs to be evaluated against a more holistic set of criteria' $(2012,19)$.

But how are we to develop this more 'holistic set of criteria', to which Tikly refers? Bonvin and Farvaque (2006) suggest that this can only be achieved by paying attention to the procedural levels of evaluation which, according to Sen (1999), must involve a process of democratic participation that provides opportunities for this 'set of criteria' to be publicly scrutinised and debated.This participation is central to evaluation for two distinct reasons. The first, the 'evaluative reason', lies in the importance of evaluating developmental (or institutional) interventions in light of whether they have enhanced the capabilities that matter $(1999,4)$. The second, relevant to Bonvin and Farvaque's (2006) procedural levels, is the 'effectiveness reason', which derives from Sen's argument that the 'achievement of development is thoroughly dependent on the free agency of people' (Sen, 1999, 4), wherein development is understood as constitutive of freedom, and the 'expansion of freedom is viewed as both the primary end and the principal means of development' (Sen, 1999, 36). In other words, he argues that people are to be envisaged as agents capable of acting, and desiring to do so, in the world, rather than as 'motionless patients' (Sen, 1999, 137) standing in a line waiting patiently (or impatiently) to be developed. Correspondingly, failing to include people in the process of development might result in 'targetingachievements [being] quite different from targeting-attempts' (Sen, 1999, 137). 
Contrary to the emphasis placed on participation in the capability approach, current approaches to FET college evaluation have largely ignored the voices and experiences of students. Like conventional approaches to VET evaluation internationally, these evaluations tell us nothing about why these students elected to enrol, the costs to themselves and their family of said enrolment, or the extent to which the college has or has not met their expectations. The reason for this is that it is assumed that learners' voices are irrelevant, as it is 'obvious' what they want—-jobs now. As Wedekind argues:

[M] uch of the reform process [for FET colleges] cares little about understanding the people in the system [...] as long as more staff and students are black and enrolments are increasing there is little more that needs to be considered. $(2009,17)$

Recent discussions on the operationalisation of the capability approach have centred on the development of capability lists that identify the capabilities that matter to individuals and define a set of corresponding measurement dimensions or indicators (Alkire, 2002). ${ }^{4}$ Democratic participation and public debate are emphasised as essential to developing these capability lists, as the selection of capabilities to be promoted through policy and institutional interventions and the information sets used for evaluation is not neutral, but involves expediently trading the benefits of one capability, and therefore one information set, against another. As Alkire argues, 'the capability approach can be likened to a sophisticated balance upon which two states of affairs or alternative courses of action can be analysed and compared' $(2008,28)$. From this perspective, the first step towards resolving these complex decisions and the contradictions underpinning them lies in public deliberation and participation. This must be matched by expanding the 'capability of voice' through the establishment of procedures for social choice and provid-

4 It is important to note that the capabilities approach is not homogeneous. While all who work within its framework share a common commitment to social justice and the distinction between capabilities and functionings, there are a diversity of perspectives and developments. An important distinction must be drawn between the interpretations of Amartya Sen and Martha Nussbaum, who have very different approaches to the definition of capabilities and freedom, and to the development of capabilities lists. Sen believes in deliberately leaving capability lists unspecified in favour of public deliberation, while Nussbaum argues for the development of basic capabilities which governments should then constitutionally guarantee their citizens. 
ing individuals with the abilities and spaces to meaningfully express their opinions (Bonvin and Thelon, 2003).

An important motive for the development of capability lists, their role in the expansion of voice, is that enables researchers to determine whether a particular social initiative (in this case, VET institutions) has expanded or contracted capabilities that matter by developing a 'set of criteria', selected during the process of social evaluation, against which progress can be evaluated. Another benefit of capabilities lists lies in their ability to act as 'devices to focus attention' (Kamsler, 2006, 199). Highlighting Mark and Rock's (1998) work on 'inattentional blindness', Kamsler argues that what we pay attention to 'profoundly affects both our personal evaluations of well-being and our formulation of focused goals, such as political agendas' $(2006,200)$. By focusing attention on human well-being, capability lists correct for 'inattention blindness' to human flourishing.

\section{The Contribution of the Capability Approach to VET Evaluation}

On the surface, the 'procedural aspects' might appear quite similar to newer, more participatory approaches to VET evaluation, such as that put forward by Nieuwenhuis and Shapiro (2004), which have been developed in response to positivistic assumptions of the neutrality of evaluation. This literature argues for the importance, in 'high-quality evaluations', of 'acceptance and credibility of evaluations amongst programme participants' (Beywl and Speer, 2004, 55). The difference, then, lies in the underlying paradigm, with many of these 'new' approaches emphasising the importance of evaluation as a 'steering mechanism' in the context of 'deregulation and decentralisation' (Beywl and Speer, $2004,55)$ and/or the importance of systemic interaction within the skills development system (Nieuwenhuis and Shapiro, 2004). The distinction drawn in the capability approach between means and ends, and corresponding focus on human well-being, thus diverges from the human capital and productivist approaches underpinning much of contemporary evaluation research. As a result, job readiness is privileged above all other educational values. This is particularly so in VET, where the 'singular emphasis on a narrow "initiative" version of employability (Gazier and Houneman, 1999) has left little room for the role that education and training plays in preparing young people for the challenges and opportunities that they will face in their families, their communities and their workplaces' (Powell and McGrath, 2013, 9).

In contrast to the dominant, often productivist approaches to VET evaluation (Anderson, 2003), including the newer, participatory approaches discussed 
above, the capability approach provides a revised normative framework for the evaluation of VET. In general, 'productivist' approaches emphasise economic growth and income generation as key development objectives, understanding employability and the creation of human capital solely as a means to that end. Conversely, the capability approach prioritises human flourishing, with economic growth seen as a necessary but not sufficient means of achieving development. Understood in these terms, the evaluation of employability must be seen in a new light. For the capability approach, employability is more than the ability to access work; it is about 'the real freedom to choose the job one has reason to value' (Bonvin and Galster, 2010, 72). From this perspective, employability requires not only valuable opportunities to access the skills and abilities necessary for work, but also the existence of valuable opportunities that contribute to human flourishing within the labour market.

Conventional evaluation of VET's affect on learners focuses on achieving objective targets in key policy areas, such as participation, institutional effectiveness and employability, rather than on the capabilities that matter to the lives of students. As with the evaluations of the South African FET colleges discussed above, many of these new and participatory approaches to VET evaluation are guilty of 'inattention blindness' to human well-being. They fail to consider the well-being of students or the extent to which VET systems are providing real opportunities for learners to expand their options and life achievements. This is due, as argued by Grubb and Ryan, to the fact that these 'evaluations of VET programmes often fail to describe with any precision what particular programmes do; what a programme is, and why it should have any positive effects at all' (Grubb and Ryan, 1999, 8). We agree with Grubb and Ryan when they insist that 'the purpose of a particular programme should influence the kind of evaluation undertaken' $(1999,8)$. Moreover, as Sen argues, 'if freedom is what development advances, then there is a major argument for concentrating on the overarching objective, rather than on a particular means, or some chosen list of instruments' (1999, 3).

Conventional VET evaluation, while instrumental in maintaining the political and institutional accountability necessary for creating the conditions required for capability expansion, is paradigmatically limited as an approach for evaluating the contribution of VET to poverty and social inclusion. Paradoxically, however, both are key goals of South Africa's FET college policy. The orthodoxy is unable to identify the capabilities (or opportunities) that are of value to students; the extent to which VET institutions expand or restrict these valued capabilities; and the future policies and institutional trajectories required to achieve such capability expansion. As such, the emphasis on 
human well-being in the capability approach marks a major departure from productivist conceptions of VET (McGrath, 2012b; Powell, 2012; López-Fogués, 2012). Its insistence on the centrality of agency differs markedly from the dominant paradigm applied to much of VET evaluation research, which is primarily concerned with structure-the institution, the skills development system and the relationship with the economy being foremost - at the expense of students' agency and experiences (Powell, 2013).

\section{$6 \quad$ Challenges with Applying the Capability Approach}

It is beyond the scope of this chapter to survey the critiques of the capability approach, particularly as Robeyns (2005) and Alkire (2002) have already produced excellent work on the subject. There are obviously many limitations to the approach; here, we will focus on concerns regarding the operationalisation of the capability approach in social evaluations.

The use of the capability approach as a tool for the evaluation of social policy is still in its infancy (Alkire, 2008). Sen's highly philosophical approach does not lend itself easily to operationalisation. Indeed, Robeyns notes that 'some critics' frustration with Sen's capability approach seem[s] to stem in part from uncertainty as to whether or not they have "done it right"' (Robeyns, 2002, 122). The realisation that conventional evaluation approaches are inadequate may be of little value if, 'after scrutiny, we must concede that the capability approach in practice can do no better' (Alkire, 2008, 26).

Evaluation is necessarily a pragmatic exercise; it must be timely and costeffective. As such, many are rightly concerned that the capability approach may be poor value for money. At this point in time, the data to clearly address this issue simply does not exist. What we do know, however, is that the fair comparators, in terms of cost, are past VET evaluation programmes. Once such recent evaluation cost nearly EUR 400,000, which leads us to believe there is some hope for better value for money from a capability approach. Equally, having experienced week-long conventional evaluation visits to institutions, our expectation is that the time required for a capabilities-based evaluation is unlikely to be excessive in comparison.

That said, an important argument of this chapter is that, as yet, we do not know whether a capability approach to VET evaluation is viable. What we do know is that, more important than cost and time considerations, the current approach is too limited to serve the social inclusion goals of South Africa's new FET college policy framework. In this context, though it remains to be tested in 
practice, the capability approach provides a promising alternative. We believe that even if it proves limited in practice, the capability may be invaluable in highlighting the well-being of students, which justifies the need for experimentation in and of itself.

\section{$7 \quad$ Conclusion}

We will conclude this chapter with five key propositions.

First, whilst past evaluation research has made an important contribution to the establishment and reform of South Africa's FET colleges, the approach is inadequate to address the new challenges faced by the sector.

Second, a deep-held belief regarding the central importance of employability to the sector's mission lies at the heart of the current approach to determining VET's success. This narrow, Anglophone model of employability, however, neglects the roles played by policies, labour markets and employers' decisions and tends to produce an insufficient account of individual learners. We argue, moreover, that said learners are not simply empty slates enrolling at colleges in the hope of acquiring employability skills.

Third, the above arguments are linked to a wider insistence in contemporary development theory, driven by the human development and capability approach, on the multifaceted nature of development. A narrow, economistic view of development, therefore, is far too narrow to generate an adequate understanding of the role FET colleges can play in poverty alleviation, unemployment reduction and well-being enhancement.

Fourth, we believe that the sweeping assumptions frequently made as to what learners, staff and communities value from their VET experiences are fundamentally flawed. We instead agree with Cook-Sather, that there is 'something fundamentally amiss about building and rebuilding an entire system without consulting at any point those it is ostensibly designed to serve' $(2002,3)$.

Fifth, in the light of the previous four propositions, we suggest that there is a strong case for exploring the suitability of a new approach to VET evaluation that draws on the human development and capability approach.

This chapter constitutes an initial step into complex territory. It suggests there are merits in a shift in VET evaluation from the narrow areas of concentration outlined above to a broader and more humanistic vision targeted at the well-being of VET students. It must be recognised, however, as Alkire (2008) notes, that 'to operationalise an alternative approach [...] which is what the capability approach is-is not a modest task, nor is it very nearly 
accomplished' $(2008,130)$. Our next task is to offer some proposals for operationalising this approach. But that task remains for another paper.

\section{References}

Akoojee, S. and S. McGrath (2008) 'The Marketing of Public FET Colleges', Journal of Education, 45, pp. 131-153.

Alkire, S. (2008) 'Using the Capability Approach: Prospective and Evaluative Analyses' in Comim, F., M. Qizilbash and S. Alkire (eds.), The Capability Approach: Concepts, Measures and Applications (Cambridge: Cambridge University Press).

- (2002) Valuing Freedoms: Sen's Capability Approach and Poverty Reduction (Oxford: Oxford University Press).

Anderson, D. (2003) 'From Productivism to Ecologism: Dilemmas, Issues and Strategies for VET', Australian Vocational Education Review, 10(1), pp. 1-14.

Beywl, W. and S. Speer (2004) 'Developing Standards to Evaluate Vocational Education and Training' in Descy, P. and M. Tessaring (eds.) The Foundations of Evaluation and Impact Research (Luxembourg: Office for Official Publications of the European Communities).

Bonvin, J. and N. Farvaque (2006) 'Promoting Capability for Work: The Role of Local Actors' in Deneulin, S. et al., (eds.), Transforming Unjust Structures: The Capability Approach (Dordrecht: Springer).

_ (2005) 'What Informational Basis for Assessing Job-Seekers? Capabilities vs. Preferences', Review of Social Economy, 63(2), pp. 269-289.

Bonvin, J. and L. Thelon (2003) Deliberative Democracy and Capabilities: The Impact and Significance of Capability for Voice, paper presented at the 3rd Conference on the Capability Approach, Pavia.

Cloete, N. (2009) Responding to the Education Needs of Post-school Youth (Cape Town: Centre for Higher Education Transformation).

Cook-Sather, A. (2002) 'Authorizing Students' Perspectives: Toward Trust, Dialogue, and Change in Education', Educational Researcher, 31(4), pp. 3-14.

Cosser, M., et al. (2011) Further Education and Training (FET) Colleges at a Glance in 2010 FET Colleges Audit (Cape Town: Human Sciences Research Council). (2003) Technical College Responsiveness (Cape Town: HSRC Press).

Deneulin, S. and L. Shahani (2009) An Introduction to the Human Development and Capability Approach (London: Earthscan).

DHET (Department of Higher Education and Training) (2011) Green Paper for Post School Education and Training (Pretoria: Department of Higher Education and Training). 
Fisher, G., et al. (2004) 'Public Further Education and Training Colleges' in Kraak, A. and K. Press (eds.), Human Resources Development Review 2003 (Cape Town: HSRC Press). Gazier, B. and S. Houneman (1999) 'Employability: An Evolutionary Notion, an Interactive Concept' in Gazier, B. (ed.), Employability: Concepts and Policies (Berlin: European Employment Observatory Research Network).

Geel, P. (2005) The Management of Staff Development Programmes at FET Colleges in the Gauteng Province, unpublished $\mathrm{PhD}$ thesis, University of South Africa.

Gewer, A. (2009) Features of Social Capital that Enhance the Employment Outcomes of FET College Learners, unpublished PhD thesis, University of the Witwatersrand.

Grubb, W. and P. Ryan (1999) The Roles of Evaluation for Vocational Education and Training (Geneva: International Labour Organization).

Jaff, R., et al. (2004) The Challenge of Staffing Responsiveness in FET Colleges (Pretoria: Department of Education).

Kamsler, V. (2006) 'Attending to Nature: Capabilities and the Environment' in Kaufman, A. (ed.) Capabilities Equality: Basic Issues and Problems (London: Routledge).

Kraak, A., et al. (2006) Debating High Skills and Joined-Up Policy (Cape Town: HSRC Press).

López-Fogués, A. (2012) Theorising Further Education through a Capability Lens: Vulnerability and Freedoms, Jubilee Working Papers (Nottingham: School of Education, University of Nottingham).

Mark, A. and I. Rock (1998) Inattentional Blindness (Cambridge, MA: MIT Press).

McGrath, S. (2012a) 'Building New Approaches to Thinking about Vocational Education and Training and Development: Policy, Theory and Evidence', International Journal of Educational Development, 32(5), pp. 619-622.

- (2012b) 'Vocational Education and Training for Development: A Policy in Need of a Theory?', International Journal of Educational Development, 32(5), pp. 623-631.

_ (2010) 'Beyond Aid Effectiveness: The Development of the South African Further Education and Training College Sector, 1994-2009', International Journal of Educational Development, 30(5), pp. 525-534.

(2008) 'FET Needs Research', Mail and Guardian, 30 June, http://mg.co.za/ article/2008-06-30-fet-needs-research (accessed on 4 March 2014).

McGrath, S. and R. Lugg (2012) 'Knowing and Doing Vocational Education and Training Reform: Evidence, Learning and the Policy Process', International Journal of Educational Development, 32(5), pp. 696-708.

McGrath, S., et al. (eds.) (2004) Shifting Understandings of Skills in South Africa (Cape Town: HSRC Press).

Mercorio, G. and L. Powell (1999) A Report on Work Conducted amongst Stakeholders within the Western Cape: Partnerships and Linkages (Johannesburg: The Colleges Collaboration Fund, National Business Initiative). 
Nieuwenhuis, L. and H. Shapiro (2004) 'Evaluating Systems Reform in Vocational Education and Training: Learning from Danish and Dutch Cases' in Descy, P. and M. Tessaring (eds.), Evaluation of Systems and Programmes. Third Report on Vocational Training Research in Europe: Background Report (Luxembourg: Office for the Official Publications of the European Communities).

Papier, J. (2006) All Further Education and Training Colleges (FETCs) Are Equal, but Some Are More Equal Than Others (with Apologies to Orwell), Harold Wolpe Memorial Trust Open Dialogue, 2 February, Cape Town.

Powell, L. (2013) 'A Critical Assessment of Research on South African FET Colleges', South African Review of Education, 19(1), pp. 59-81.

- (2012) 'Reimagining the Purpose of VET: Expanding the Capability to Aspire in

South African Further Education and Training Students', International Journal of Educational Development, 32(5), pp. 643-653.

Powell, L. and G. Hall (2004) Quantitative Overview of the Further Education and Training College Sector (Pretoria: Department of Education).

- (2002) Quantitative Overview of the Further Education and Training College Sector (Pretoria: Department of Education).

- (2000) Quantitative Overview of the South African Technical Colleges (Pretoria:

Department of Education).

Powell, L. and S. McGrath (2013)Advancing Life Projects: South African Students Explain

Why They Come to FET Colleges, Presented at the Journal Vocational Education and

Training Conference, Researching Vocational Education and Training, Worcestor College, Oxford, 5-7 July.

Qizilbash, M. and D. Clark (2002) Core Poverty and Extreme Vulnerability in South

Africa, Economics Research Centre Discussion Paper, No. 2002-3, University of East Anglia.

Robeyns, I. (2005) 'The Capability Approach: A Theoretical Survey', Journal of Human Development, 6(1), pp. 93-117.

_ (2003) 'Sen's Capability Approach and Gender Inequality: Selecting Relevant Capabilities', Feminist Economics, 9(2-3), pp. 61-92.

Sen, A. (2009) The Idea of Justice (London: Belknap Press).

(2005) 'Human Rights and Capabilities', Journal of Human Development, 6(2),

pp. 151-166.

— (1999) Development as Freedom (Oxford: Oxford University Press).

(1992) Inequality Reexamined (Oxford: Oxford University Press).

Tikly, L. (2012) Reconceptualising TVET and Development: Towards a Capabilities and

Social Justice Approach, background paper for the World Report on TVET (Paris: UNESCO).

UNESCO (2014) Transforming Technical and Vocational Education and Training (Paris: UNESCO). 
Walker, M. (2008) 'A Human Capabilities Framework for Evaluating Student Learning', Teaching in Higher Education, 13(4), pp. 477-487.

(2005) 'Amartya Sen's Capability Approach and Education', Educational Action Research, 13(1), pp. 103-110.

Walker, M. and E. Unterhalter (2010) Amartya Sen's Capability Approach and Social Justice in Education (Basingstoke: Palgrave Macmillan).

Wedekind, V. (2009) Report on the Research on Further Education and Training (FET) Colleges in South Africa, EAP project working paper 2, University of Nottingham. 